\title{
THE EFFECT OF DISTRACTION THERAPY (PRAY) TO THE SURGICAL PAIN INTENSITY AMONG POST-SPINAL ANESTHESIA PATIENTS AT ANDI SULTHAN DAENG RADJA HOSPITAL'S RECOVERY ROOM, BULUKUMBA REGENCY OF SOUTH SULAWESI
}

\author{
Syamsul Hidayat ${ }^{1}$, Yustiana Olfah' ${ }^{2}$, Sugeng ${ }^{3}$ \\ yustianajogja@gmail.com
}

\begin{abstract}
Background: The needs of pain free after surgery occurs when analgesic medicine effect is run out. Thus, nursing care with distraction therapy can lead to the reduce of such pain sensation (Prasetyo, 2010). One of independent nursing interventions to relieve patients' pain is to measure pain scale and then to give further intervention, either relaxation or distraction.

Objectives: To identify the effect of distraction therapy, which is pray, to the surgical pain intensity of post-spinal anesthesia patients at Sulthan Daeng Radja hospital's recovery room, Bulukumba regency of South Sulawesi

Methods: A quasi experiment with one group pretest-posttest design was used in this research. The samples group was measured with pretest before being given an intervention and it was being re-measured after the intervention (posttest). Samples were chosen through non-random sampling, which is purposive sampling. Thirty eight samples were involved and being given such distraction therapy throughout the period of August $26^{\text {th }}$ to October $19^{\text {th }} 2013$.

Results: There was a significant result shown by using McNemar-analysis ( $p$ value $=0.00$ ). This reveals that there were decline in pain intensity after such distraction therapy among such patients.

Conclusions: Distraction therapy (praying) reduces surgical pain intensity after spinal anesthesia. Therefore it can be used as an independent nursing intervention among patients hospitalized with pain problems.
\end{abstract}

Keywords: Spinal anesthesia, pain intensity, distraction therapy (pray)

\section{PENDAHULUAN}

Kebutuhan terbebas dari rasa nyeri atau perasaan yang tidak menyenangkan yang dialami individu setelah operasi atau masa kerja obat analgetik telah habis adalah salah satu kebutuhan dasar yang merupakan tujuan diberikannya asuhan keperawatan pada seorang pasien di rumah sakit. Dalam memberikan asuhan keperawatan guna mengatasi rasa nyeri pada pasien, perawat harus selalu berusaha untuk mengembangkan strategi penatalaksanaan nyeri. ${ }^{1}$

Nyeri selalu dikaitkan dengan adanya stimulus (rangsangan nyeri) dan reseptor. Reseptor yang dimaksud adalah nosiseptor yaitu ujung saraf bebas pada kulit yang berespon terhadap stimulus yang kuat, baik berupa dari stimulus biologi, zat kimia, panas, listrik serta mekanik ${ }^{1}$. Respon tubuh terhadap stimulus

\footnotetext{
${ }^{1}$ RSUD H. Andi Sulthan Daeng RadjaKabupaten Bulukumba Sulawesi Selatan

${ }^{2}$ Dosen Jurusan Keperawatan Politeknik Kesehatan Kemenkes Yogyakarta

${ }^{3}$ Dosen Jurusan Keperawatan Politeknik Kesehatan Kemenkes Yogyakarta
} 
akan merugikan pasien, karena akan menurunkan daya tahan tubuh pasien serta meningkatkan kebutuhan oksigen. Keadaan ini seperti ini sangat mengganggu kehidupan normal pasien, oleh karena itu penatalaksanaan nyeri pada hakikatnya tidak saja tertuju pada mengurangi nyeri itu sendiri melainkan bermaksud menjankau peningkatan mutu kehidupan pasien. $^{2}$

Perawatan post anestesi dilakukan diruang pulih sadar (Post Anesthesia Recovery Room), yaitu ruang khusus di dalam instalasi bedah yang merupakan tempat dilakukan observasi dan perawatan post anestesi sampai pasien dinyatakan aman dari pengaruh abat-obatan anestesi. Karena keadaan tidak memungkinkan untuk pasien dirawat lama diruang recovery room, pasien di pindahankan keruang pulih post bedah. Pasien dengan general anestesi maupun dengan regional anestesi yang mendapatkan analgetik narkotik masih harus dibawa pengawasan bagian anestesi selama $12-24$ jam. $^{3}$

Efek obat dipengaruhi banyak faktor yang tentu saja berpengaruh terhadap durasi kerja obat, rata-rata lama durasi obat-obatan anestesi spinal sekitar $4-6$ jam. Sesudah 4-6 jam efek analgetik obat anestesi akan berkurang sehingga pasien akan mulai merasakan sakit pada luka operasi, nyeri berat akut yang dirasakan pasien dapat dihilangkan atau dikurangi dengan menggunakan analgetik murni atau anelgetik narkotik. Analgetik murni diberikan untuk nyeri ringan dan sedang serta untuk nyeri berat dengan analgetik narkotik. Pemberian analgetik dapat dengan cepat merendakan nyeri tetapi bukan berarti tidak mempunyai efek samping dan langsung meredahkan nyeri tetapi mebutuhkan durasi waktu hingga efek obat yang diingin akan bekerja. ${ }^{3}$

Sebagian besar pasien post anestesi akan mengalami nyeri meskipun telah diberi terapi farmakologi, terutama saat selang waktu pemberian analgetik. Pada waktu itulah seharusnya perawat akan memberikan intervensi atau mengajari pasien manageman nyeri non farmakologi agar nyeri berkurang sehingga dengan mengkombinasikan tehnik distraksi dan analgetik mungkin cara yang paling efektif mengurangi atau menhilangkan rasa nyeri. ${ }^{4}$

Salah satu fungsi mandiri perawat dalam mengatasi masalah nyeri antara lain melakukan pengukuran tingkat nyeri kemudian memberikan intervensi untuk mengatasi nyeri yaitu dengan tehnik relaksasi dan distraksi. Dimana perawat anestesi dapat menganjurkan dan membimbing pasien untuk mengatasi masalah nyeri yang dialami pasien, sehingga pasien dapat merasa nyaman saat nyeri itu berkurang. Untuk mengatasi nyeri banyak pasien dan anggota tim kesehatan cenderung memandang obat sebagai satu-satunya metode untuk menghilangkan nyeri. Namun begitu banyak aktivitas keperawatan nonfarmakologis yang dapat mambantu dalam mengurangi rasa nyeri, misalnya intervesi keperawatan distraksi atau relaksasi meskipun ada beberapa laporan anekdot mengenai keefektifan tindakantindakan tersebut, sedikit diantaranya yang belum dievaluasi melalui penelitian riset yang sistematik. ${ }^{1}$

Pengaruh agama dalam penyembuhan penyakit dalam pembahasan utamanya. Majalah tersebut melaporkan bahwa dengan berdoa dapat meningkatkan harapan pasien dan membantu pemulihan mereka dengan mudah, dan bahwa ilmu pengetahuan mulai meyakini bahwa pasien dengan berdoa akan pulih lebih cepat dan lebih mudah. $^{5}$ Menurut pendataan oleh Newsweek, $72 \%$ masyarakat Amerika mengatakan mereka percaya bahwa berdoa dapat menbantu kesembuhkan penyakit. Penelitian di Inggris dan Amerika Serikat menyimpulkan bahwa doa dapat mengurangi gejala-gejala penyakit pada pasien dan mempercepat proses penyembuhan.

Doa merupakan suatu hal penting yang tak terpisahkan dari kehidupan manusia, dalam kondisi apapun baik sehat maupun dalam keadaan sakit. Sebaiknya kita berdoa kepada Allah SWT setiap saat karena Allah SWT akan selalu mendengarkannya. ${ }^{6}$ Tehnik distraksi berdoa dapat digunakan individu dalam kondisi sehat maupun sakit merupakan upaya pencegahan untuk membantu tubuh segar kembali dengan meminimalkan nyeri 
secara efektif. ${ }^{7}$ Adapun keuntungan dari tehnik distraksi ini dapat digunakan kapan saja dan caranya mudah, murah sehingga dapat dilakukan secara mandiri oleh pasien. Kerugiannya tidak semua pasien memiliki keyakinan yang sama sehingga cara dan isi doa berbeda-beda. ${ }^{8}$

Kabupaten Bulukumba merupakan salah satu kabupaten di Sulawesi Selatan dengan pemerintahan yang memiliki PERDA syariat Islam sejak tahun 2003 yang berisi tentang baca tulis Al Qur'an, pemberantasan miras dan berpakaian muslim serta zakat profesi, infaq dan shadaqah. RSUD H. A. Sulthan Daeng Radja satu-satunya rumah sakit yang berada di Kabupaten Bulukumba. Dari laporan rekam medik RSUD H. A. Sulthan Daeng Radja Kabupaten Bulukumba jumlah kasus operasi rata-rata 150 perbulan mulai dari Januari sampai Mei 2013, dari berbagai diagnosa medis. Setiap bulan rata-rata $40 \%$ (60 orang) diantaranya dilakukan regional anestesi atau $28 \%$ (42 orang) dengan spinal anestesi dan selebihnya dengan general anestesi serta lokal anestesi.

Data tersebut menunjukkan setiap pasien berpotensi mengalami nyeri akut akibat proses pembedahan, di ruangan recovery room dan ruang perawatan bedah. Kebiasaan perawat di RSUD H. A. Sulthan Daeng Radja Kabupaten Bulukumba untuk mengatasi nyeri berdasarkan observasi peneliti, perawat hanya menganjurkan pasien untuk melakukan relaksasi nafas dalam tetapi belum ada protap yang mengatur tentang intervensi keperawatan mandiri untuk mengatasi nyeri pasien, dengan demikian pasien dapat merasa nyaman atau nyeri berkurang, tindakan medis dalam hal ini pemberian analgetik merupakan satusatunya pilihan. Studi awal yang dilakukan pada 10 respoden dengan menggunakan distraksi berdoa untuk menurunkan intensitas nyeri menujukkan hasil bahwa ada 7 responden merasa nyaman setelah dilakukan distraksi berdoa.

Berdasarkan uraian pada latar belakang tersebut, maka dapat di rumuskan pertanyaan penelitian "Bagaimana pengaruh distraksi berdoa terhadap intensitas nyeri operasi pada pasien post spinal anestesi di recovery room H. A. Sulthan Daeng Radja Kabupaten Bulukumba Sulawesi Selatan?".

Tujuan dari penelitian ini untuk mengetahui pengaruh distraksi berdoa terhadap intensitas nyeri operasi pada pasien post spinal anestesi di recovery room RSUD H. A. Sulthan Daeng Radja Kabupaten Bulukumba Sulawesi Selatan

\section{METODE}

Berdasarkan tujuannya jenis penelitian ini menggunakan penelitian Quasi Experiment dengan rancangan, One Group Pretest Posttest yaitu dengan cara memberikan pre test terlebih dahulu sebelum diberikan intervensi kemudian, diberikan intervensi lalu, dilakukan kembali post test, ${ }^{9}$ yang dilakukan di RSUD $\mathrm{H}$. A. Sulthan Daeng Radja Kabupaten Bulukumba Sulawesi Selatan pada tanggal 26 Agustus sampai 19 Oktober 2013.

Pengumpulan data dalam penelitian ini berupa lembar observasi untuk mengetahui intensitas nyeri pasca operasi sebelum dan sesudah perlakuan dengan tehnik distraksi berdoa. Lembar observasi terdiri dari dua bagian yaitu: Karakteristik responden data pasien diperoleh cara dengan melakukan wawancara terhadap pasien dan keluarganya. Dan Lembar observasi nyeri skala VAS digunakan untuk mengobservasi tingkat nyeri yang dialami pasien sebelum dan sesudah perlakuan.

\section{HASIL DAN PEMBAHASAN}

Responden dalam penelitian ini berjumlah 38 responden. Semua responden yang diteliiti dalam penelitian ini merupakan responden yang mendapat anestesi regional dengan tehnik spinal dan tidak mendapat obat analgetik tambahan pada intra dan post operasi sebelum diberikan perlakuan penelitian. Dalam penelitian ini yang berhubungan dengan karakteristik responden adalah jenis kelamin, umur dan pendidikan seperti berikut ini: 
Distribusi Frekuensi Karakteristik Responden

\begin{tabular}{lcc}
\hline \hline \multicolumn{1}{c}{ Karakteristik } & Frekuens & Prosentase \\
\hline & & \\
a. Jenis kelamin & 19 & 50,00 \\
Laki- Laki & 19 & 50,00 \\
$\quad$ Perempuan & & \\
\hline b. Umur & 18 & 47,37 \\
21-34 Devasa aval & 20 & 52,63 \\
35-45 devasa akhir & 20 & \\
\hline C. Pendidikan & 10 & 26,32 \\
SMP & 20 & 52,63 \\
SMA & 8 & 21,05 \\
PT & & \\
\hline \hline
\end{tabular}

Tabel 1 menunjukkan distribusi frekuensi 38 responden dengan perlakuan distraksi berdoa pasca anestesi spinal diruang recovery room RSUD $\mathrm{H}$. Andi Sulthan Daeng Radja Bulukumba yaitu responden yang berjenis kelamin laki - laki sebanyak 19 (50\%) dan yang berjenis kelamin perempuan juga sebanyak 19 $(50 \%)$, dari segi umur responden dalam penelitian ini semuanya berumur dewasa namun dikelompokan menjadi dewasa awal $18(47,37 \%)$ dan dewasa akhir 20 $(52,63 \%)$, pendidikan responden yang terbanyak adalah kelompok SMA 20 $(52,63 \%)$ di ikuti kelompok SMP 10 $(26,32 \%)$ dan kelompok perguruan tinggi sebanyak $8(21,05)$.

Ada banyak faktor yang dapat mempengaruhi nyer ${ }^{1}$, pada jenis kelamin prosentase responden laki-laki $19(50 \%)$ maupun responden perempuan 19 (50\%) yang mengalami nyeri sama besarnya, dan usia kondisi nyeri hebat pada dewasa muda dapat dirasakan sebagai keluhan ringan, pada dewasa tua mengalami perubahan neurofisiologi dan mungkin mengalami penurunan presepsi sensori stimulus serta menigkatkan ambang nyeri. Pada penelitian ini umur responden semuanya berumur dewasa namun dikelompokan menjadi dewasa awal 18 $(47,37 \%)$ dan dewasa akhir 20 (52,63\%). Selain itu proses penyakit kronis yang lebih umum terjadi pada dewasa tua seperti penyakit gangguan kardiovaskuler atau diabetes mellitus mengganggu trasmisi inpuls saraf normal (Mode \& Burke 1998 dalam Indryati, 2008).

Identifikasi intensitas nyeri sebelum dilakukan distraksi berdoa pada 38 responden berdasarkan VAS yaitu:

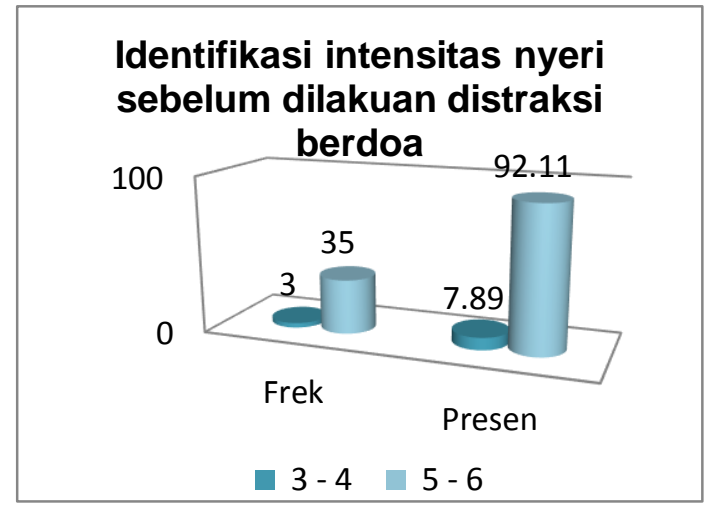

Dapat dilihat pada grafik diatas identifikasi intensitas nyeri sebelum dilakukan distraksi berdoa pada 38 responden berdasarkan VAS yaitu sebanyak $3(7,89 \%)$ responden dengan nilai intensitas nyeri $3-4$ serta nilai intensitas nyeri $5-6$ sebanyak 35 $(92,11 \%)$ responden.

Identifikasi intensitas nyeri sesudah dilakukan distraksi berdoa pada 38 responden berdasarkan VAS yaitu:

\section{Identifikasi intensitas nyeri sesudah dilakuan distraksi berdoa}

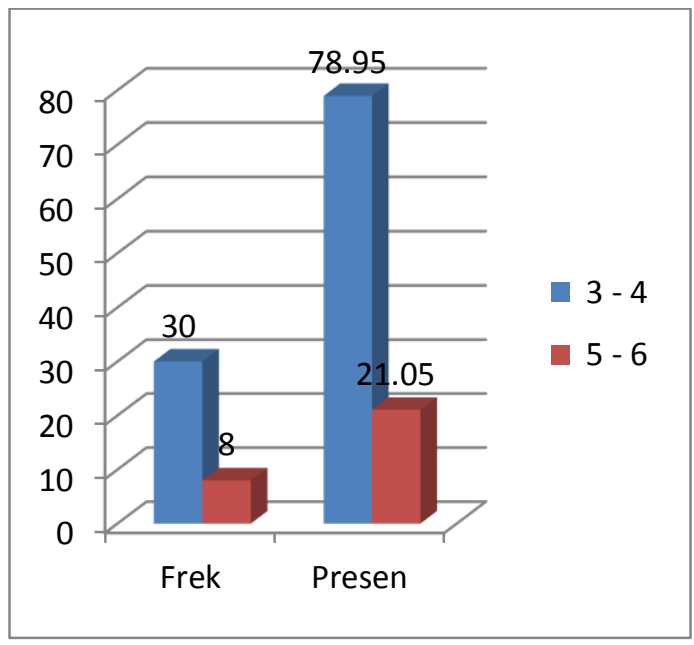

Dari grafik di atas menunjukkan intensitas nyeri $3-4$ sesudah distraksi berdoa dilakukan sebanyak 30 (78,95\%) responden sedangkan pada intensitas nyeri 5 - 6 sebanyak 8 (21,95\%) responden setelah dilakukan.

Uji statistik perubahan intensitas nyeri setelah diberikan perlakuan distraksi berdoa dilakukan pada 38 responden dapat dilihat pada tabel berikut: 


\section{Uji statistik perubahan intensitas nyeri setelah diberikan perlakuan distraksi berdoa}

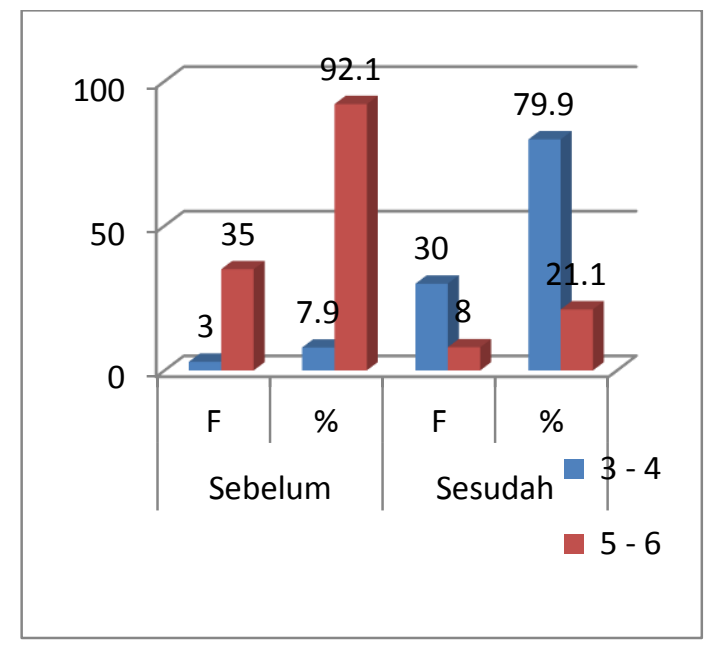

Uji hipotesis non parametrik dengan McNemar test dengan mengelompokkan nilai intensitas nyeri yaitu berdasarkan dapat dilihat pada grafik diatas intensitas nyeri $3-4$ sebelum dilakukan distraksi berdoa sebanyak 3 (7,9\%) responden dan sesudah dilakukan distraksi berdoa meningkat menjadi sebanyak 30 (78,9\%) responden, sedangkan untuk nilai intensitas nyeri 5 - 6 sebanyak $35(92,1 \%)$ responden sebelum dilakukan distraksi dan sesudah dilakukan distraksi berdoa menurun menjadi sebanyak $8 \quad(21,1 \%)$ responden, maka dengan $\mathrm{McNemar}$ test yang dilakukan didapatkan hasil nilai $p \leq$ $0,05(p=0,00)$ hasil ini menunjukkan adanya pengaruh distraksi berdoa terhadap intensitas nyeri sebelum dan sesudah diberikan perlakuan.

Penelitian serupa yang dilakukan Sobirin (2010). Pengaruh terapi doa dalam menurunkan nyeri pada pasien pasca operasi fraktur femur di RSKB Siaga Medika Banyumas. Dengan hasil ada perbedaan secara signifikan pada kelompok yang diberikan intervensi, atau pada penelitian yang dilakukan oleh Agustiawan (2012). Pengaruh pemberian tehnik relaksasi nafas dalam terhadap perubahan tingkat nyeri pasca operasi dengan general anestesi di RSUD Muntilan Kabupaten Magelang. Dengan hasil ada pengaruh secara signifikan pada kelompok yang diberikan intervensi tehnik relaksasi nafas dalam. Persamaan penelitian ini yaitu bertujuan ingin meneliti cara menurunkan intensitas nyeri, sehingga dapat disimpulkan bahwa ada banyak cara untuk menurunkan intensitas nyeri salah satunya dengan distraksi berdoa.

Hal ini membuktikan bahwa salah satu fungsi perawat adalah fungsi mandiri diantaranya melakukan pengukuran tingkat nyeri kemudian memberikan intervensi untuk mengatasi nyeri yaitu dengan tehnik relaksasi dan distraksi. Dimana perawat anestesi dapat menganjurkan dan membimbing pasien untuk mengatasi masalah nyeri yang dialami pasien, sehingga pasien dapat merasa nyaman saat nyeri itu berkurang. Untuk mengatasi nyeri banyak pasien dan anggota tim kesehatan cenderung memandang obat sebagai satu-satunya metode untuk menghilangkan nyeri. Namun begitu banyak aktivitas keperawatan nonfarmakologis yang dapat mambantu dalam mengurangi rasa nyeri, misalnya intervesi keperawatan distraksi atau relaksasi meskipun ada beberapa laporan anekdot mengenai keefektifan tindakan tersebut, sedikit diantaranya yang belum dievaluasi melalui penelitian riset yang sistematik. ${ }^{1}$

\section{SIMPULAN}

Penelitian ini dilakukan di recovery room RSUD H. A. Sulthan Daeng Radja Kabupaten Bulukumba diperoleh data hasil penelitian dan analisisnya yang telah diuraikan dalam pembahasan, maka dapat ditarik kesimpulan bahwa :

1. Intensitas nyeri operasi sebelum diberikan distraksi berdoa pada pasien post spinal anestesi yaitu berada pada rentang nilai skala intensitas $4-6$.

2. Intensitas nyeri operasi sesudah diberikan distraksi berdoa pada pasien post spinal anestesi yaitu berada pada rentang nilai skala intensitas $3-5$.

3. Distraksi berdoa pada pasien post anestesi spinal berpengaruh pada intensitas nyeri sesudah diberikan perlakuan.

4. Ada pengaruh distraksi berdoa terhadap intensitas nyeri operasi 
sesudah dilakukan distraksi pada pasien post anestesi spinal.

\section{SARAN}

Berdasarkan hasil dan kesimpulan penelitian di atas, maka saran yang dapat diberikan adalah:

1. Untuk RSUD H. Andi Sulthan Dg Radja Bulukumba

Dalam rangka upaya peningkatan mutu pelayanan kepada pihak manajemen diharapkan hasil penelitian ini dapat dijadikan sebagai Sebagai bahan kajian dan masukan dalam penyusunan Standar Operasional Prosedur (SOP) untuk intervensi tindakan mandiri perawat dalam hal teknik managemen nyeri.

2. Perawat

Sebagai informasi dalam melaksanakan tugas dan fungsi dalam memberikan asuhan keperawatan profesional sebagai bentuk tindakan mandiri perawat, dan melanjutkan peneliti ini

a. Dalam penelitian ini dilakukan di recovery room dengan distraksi berdoa yang digunakan adalah doa menurut agama islam, sehingga disarankan dalam penelitian selanjutnya digunakan doa yang bisa mencakup semua agama yang berada pada ruang perawatan.

b. Faktor - faktor yang mepengaruhi tingkat nyeri sangat penting diperhatikan dalam pengkajian sehingga mendapat hasil yang benar-benar sesuai dengan kondisi dan kebutuhan pasien.

3. Poltekkes Kemenkes Yogyakarta

Sebagai masukan dalam proses belajar mengajar bahwa dalam mengatasi nyeri pasca operasi dengan regional anestesi dapat dilakukan tindakan mandiri perawat yaitu dengan distraksi berdoa.

\section{Ucapan Terima Kasih}

1. Direktur Poltekkes Kemenkes Yogyakarta.

2. Direktur RSUDH. A. Sulthan Dg Radja Kabupaten Bulukumba Sulawesi Selatan yang telah memberikan ijin untuk belajar dan semua staf yang memberikan dukungan langsung dan tidak langsung.

3. Semua pihak yang tidak dapat disebutkan satu persatu baik yang telah memberikan moril maupun materil.

\section{DAFTAR PUSTAKA}

Prasetyo, Sigit Nian., (2010). Konsep dan Proses keperawatan Nyeri. Cetakan Pertama. Surakarta : Graha IImu

Mangku, Gde., Senapathi T. Gde Agung,. (2010). Buku Ajar IImu Anestesi dan Reanimasi,. Cetakan Pertama. Jakarta : Indeks

Morgan, G.E (2006). Patiens Monitors. In: Morgan, G.E, Mikhail MS, Murray MJ eds. Clinical Anesthesilogy

Smeltzer, Suzanne C. 2001. Buku Ajar Keperawatan Medikal Bedah Brunner \& Suddarth. Edisi 8. Volume 1. Jakarta : EGC.

Majalah Newsweek edisi 10 November 2003.

Syarif, Majmu'., (2012). Himpunan Doa dan Ibadah Sepanjang Masa. Cetakan ke V. Jakarta : Arifa Publishing

Tamsuri, Anas., (2007). Konsep dan Penatalaksanaan Nyeri. Cetakan Pertama. Pamekasan : EGC

Nuraeni, Neni., (2009). Kumpulan Doa Makbul. Edisi III. Bandung : Mutiara Media

Hidayat, A Azis Alimul. (2006). Pengantar Kebutuhan Dasar Manusia : Aplikasi Konsep \& Proses Keperawatan. Jakarta : Salemba Medika. 